\title{
A ESPECIAL CONSIDERAÇÃO DO OUTRO NA VIRTUDE DA JUSTIÇA NA ÉTICA DO ARISTÓTELES MADURO
}

\author{
THE SPECIAL CONSIDERATION OF THE OTHER IN THE VIRTUE OF JUSTICE IN THE ETHICS OF \\ THE MATURE ARISTOTLE
}

Nuno Manuel Morgadinho dos Santos Coelho*

\begin{abstract}
Resumo:
O texto examina um dos traços caracterizadores da justiça no catálogo aristotélico das virtudes éticas: a implicação do outro. A partir da constatação de que o outro é requerido em toda situação ética - e assim marca a constituição de toda virtude ética - com que sentido Aristóteles afirma ser a alteridade o traço distintivo da justiça em sentido específico?
\end{abstract}

Palavras-chave: Aristóteles. Ética. Justiça.

\begin{abstract}
:
The paper examines one of the strong lines of the justice in the Aristotelian list of ethical virtues: the implication of the other. But since the moment we verify that the presence of the other marks any ethical situation - and then that it marks the constitution of every ethical virtue - what does Aristotle mean when he affirms the otherness as the singular trace of justice in particular sense?
\end{abstract}

Keywords: Aristotle. Ethics. Justice.

Introdução

O horizonte da justiça

O Livro $\mathrm{V}$ da Ética a Nicómaco $(E N)$, dedicado à virtude da justiça, reúne as páginas de Aristóteles mais conhecidas entre juristas. Sobre este Livro há inúmeros comentários e são muito ricos os seus temas. Meu objetivo aqui não consiste em reconstruir integralmente a doutrina da justiça de Aristóteles, e por isso a exposição deste Livro é apenas parcial, com ênfase nos aspectos particularmente interessantes face ao que pretendo finalmente tematizar.

A aproximação sistemática da virtude ética da justiça (dikaiosunê) exige a delimitação do seu âmbito de ação e de seu fim e a investigação de que tipo de disposição intermédia se trata, que se ilumina face aos seus extremos. Também aqui Aristóteles segue o método de procurar, entre a faticidade do que fenomenologicamente se lhe apresenta,

\footnotetext{
* Professor Doutor de Filosofia do Direito e Disciplinas Básicas da Faculdade de Direito de Ribeirão Preto da Universidade de São Paulo.
} 
o ponto de partida para o aprofundamento filosófico do seu objeto. ${ }^{1}$ Trata-se, então, de tomar em consideração o que comumente se entende por justiça, descrita como disposição do caráter que funda o agir com justiça, fazendo desejar o que é justo. ${ }^{2} \mathrm{~A}$ atividade do homem (na ética, o seu agir) revela e ao mesmo tempo constitui o seu modo de ser (o seu caráter), explicitando-se a circularidade constitutiva entre ser (estar constituído com um determinado caráter) e o agir. Mas nesta passagem Aristóteles quer chamar a atenção para o fato de que é a condição do caráter que determina o agir, ${ }^{3}$ procurando enfatizar a justiça não como uma qualidade dos atos do homem, mas como o seu próprio modo de ser enquanto homem sério, de caráter.

Aristóteles encontra diferentes usos da palavra "justiça" na língua grega. ${ }^{4}$ A palavra "injusto" é usada para referir quem transgride a lei, quem quer mais do que é devido, e quem é iníqüo. Justo é quem observa a lei e quem respeita a igualdade. A disposição justa, assim, comparece como observância da lei e como respeito pela igualdade, e a disposição injusta, como transgressão da lei e desrespeito pela igualdade. Não são idênticos os sentidos com que se usa a palavra "justiça" como respeito à lei e como respeito à igualdade - isso deve ficar claro sempre quando se tratar das relações entre a lei e a justiça - mas é importante assinalar como são, declaradamente e desde o início, muitos ligadas.

O justo e o injusto determinam-se no horizonte da relação entre os homens, mediada pelos bens exteriores; trata-se especialmente da repartição dos bens de que depende o êxito e o fracasso..$^{5}$ A justiça, como virtude do desejar adequadamente, é excelência do

\footnotetext{
Sobre o método que parte dos phainómena, vide NUSSBAUM, Martha Craven. La fragilidad del bien. Fortuna y ética en la tragedia y la filosofía griega. Traducción de Antonio Ballesteros. Madrid: Visor, 1995. p. 318 e ss.: "Quando Aristóteles declara que, tanto na ciência e na metafísica como na ética, seu propósito é salvar as aparências e sua verdade, não faz uma afirmação intelectualmente fácil ou aceitável. Vistas no marco da filosofia eleática e platônica, suas observações adquirem um tom desafiador. Aristóteles promete reabilitar a medida desacreditada do antropocentrismo trágico e protagórico. Promete edificar sua obra filosófica no lugar de que Platão e Parmênides dedicaram suas vidas para tentar sair. Insiste em que encontrará sua verdade no interior do que dizemos, vemos e cremos, e não 'distantes do caminho dos seres humanos (...)"' (grifos no original). Sobre o antropocentrismo aristotélico, é essencial ter em conta ainda esta sua advertência: "importa ter em conta que o antropocentrismo não implica necessariamente relativismo. Como indicamos em seu momento, o Protágoras de Platão não é relativista (...); provavelmente, o mesmo caberia dizer do personagem histórico. Assim, Aristóteles promete uma volta desde a busca de uma justificação externa a uma interioridade profundamente enraizada na tradição grega, embora oposta a determinada concepção filosófica".

$2 E N, \mathrm{~V}, 1,1129$ a 5-8: "everybody means by Justice that moral disposition which renders men apt to do just things, and which causes them to act justly and to wish what is just". ARISTOTLE. Nicomachean Ethics. Translated by H. Rackham. London, Cambrigde: Harvard University Press, Willian Heinemann, 1934.

$E N, \mathrm{~V}, 1$.

$E N, \mathrm{~V}, 1$.

5 Ferraz Junior esclarece tratar-se de "um campo da ação humana em que justiça e injustiça são aplicadas particularmente, que corresponde à esfera da honra, do dinheiro, da segurança, onde a injustiça tem em vista o prazer proveniente do ganho ilícito e a justiça, o ganho eqüitativo. Essa esfera corresponde ao que Aristóteles denomina de "bens exteriores", que são aqueles que interessam à prosperidade e à adversidade" $(E N, \mathrm{~V}, 2,1129$
} 
homem que não deseja, destes bens, nem mais nem menos do que a parte que lhe cabe, enquanto o iníqüo quer demais do que é bom e de menos do que é mau.

Desenvolvimento

Lei e justiça

O problema da lei, que é um dos temas mais importantes no contexto do que quero discutir aqui. Na medida em que a tradição atribui à palavra "injusto" o sentido de transgressor da lei, e admite-se que o justo mantém-se dentro dos limites da lei, pode-se concluir que toda legalidade é de alguma forma justa. ${ }^{6}$

Mas esta afirmação não-implica uma assimilação pura e simples da justiça à legalidade em Aristóteles. Toda lei é "de certa forma" justa, diz o texto, e é preciso sublinhar e compreender bem o sentido desta afirmação. A felicidade apenas pode ser encontrada na vida ética e a vida ética apenas pode desenvolver-se sob a égide de uma comunidade (ética e política), que se estabelece como associação no marco de um determinado regime político (constituição, lei) que a institui; não há vida ética sem política e sem lei, e assim a lei é a condição de possibilidade da vida ética, de todo e qualquer esforço de conformação do caráter; por conseqüência, qualquer lei, sendo melhor do que lei nenhuma, é, “de alguma maneira", justa.

Não há ética (e portanto não há justiça) senão nos quadrantes da lei, e aqui se encontra um dos pontos de justificação de uma das acepções da justiça (que afirma o justo como o que respeita a lei). Isso está evidentemente relacionado com a idéia de que o justo e o injusto se apuram em referência à ordem política vigente. Mas isso não-implica que na visão de Aristóteles lei e justiça se identifiquem, ou que toda lei seja, ipso facto, justa, pois esta interpretação tornaria sem sentido inúmeras outras passagens em que Aristóteles se dedica a criticar a lei. Tornaria sem sentido a quase totalidade de sua Política, consagrada a investigar e reafirmar o melhor regime político, girando em torno de saber qual a melhor lei. Se toda lei fosse justa simplesmente por ser lei, que sentido teria pensar e criticar as diversas constituições históricas e conceber um regime ideal?

\footnotetext{
b 3), e segue chamando atenção para o "significado primordial na vida humana" que assume, lembrando a sua participação na realização da felicidade, supremo bem ético. FERRAZ JUNIOR, Tércio Sampaio. Estudos de filosofia do direito. Reflexões sobre o poder, a liberdade, a justiça e o direito. 2. ed. São Paulo: Editora Atlas, 2003. p. 180-181.

$6 \quad E N, \mathrm{~V}, 1,1129$ b 11-14.

7 EN, V, 1, 1129 b 12, pos dikaia, “de certa maneira justo".
} 
A observação empírica mostra que as leis se baseiam ora no interesse comum ora no interesse de alguns. ${ }^{8}$ Aqui está uma chave para a crítica da justiça da lei na Política (permitindo distinguir os regimes sãos dos regimes corrompidos). De qualquer forma, Aristóteles observa que são as leis o que, nos quadrantes de uma comunidade política concreta (e a vida ética só é concebível nos horizontes da vida comum) produz e resguarda a felicidade, seja a felicidade de cada membro da associação, seja a felicidade de toda a comunidade. ${ }^{9}$ Mas isso não-implica que toda lei seja a princípio e absolutamente justa, ou-não se poderia conceber como Aristóteles pode afirmar, logo em seguida, que a lei será justa se tiver sido corretamente disposta pelo legislador, e, caso seja "extemporânea", poderá não ser justa. ${ }^{10}$ Ele não abre mão de um ponto de vista a partir do qual o próprio legislador pode ser criticado, e está falando de um ponto de vista "de justiça", o que impede a simples equiparação entre justiça e lei.

É preciso insistir nas relações entre a lei e a justiça, e continuo a acompanhar o fio argumentativo de Aristóteles, no Livro V da Ética a Nicômaco. A lei não apenas relaciona-se com a virtude da justiça em sentido particular, mas prescreve ações a realizar no tocante a todas excelências e perversões do caráter. O objeto da lei é evidentemente muito diferente hoje, quando o legislador não tem em mira os mesmos fins visados pelo "legislador" de que fala Aristóteles. Aristóteles pensa no fundador da associação política, ou em seus grandes reformadores, que imprimem à polis a direção matricial capaz de orientar o viver público em larga perspectiva. Isso tem pouco a ver com as normas que regulam hoje as coisas do Estado no seu dia-a-dia (a que se atribui o sentido de administração) e nem com o que compete à atual legislação ordinária. A lei assume na tradição grega natureza sagrada, e não são admitidas à discussão quaisquer propostas de reformulação senão com muita gravidade. ${ }^{11}$ Uma certa leitura da Política revela que o sentido aristotélico de "legislador" aproxima-se mais do que hoje se chama de "Constituinte", persistindo porém ainda a diferença respeitante ao tipo de matéria sobre que dispõem. O legislador grego

$E N, \mathrm{~V}, 1,1129$ b $13-16$.

$E N, \mathrm{~V}, 1,1120 \mathrm{~b} 17-19$. Rackham traduz: "so that in one of its senses the term 'just' is applied to anything that produces and preserves the happiness, or the component parts of the happiness, of the political community". ARISTOTLE. Nicomachean Ethics. cit. Aristóteles assinala na Política, IV, 1294 a 1-6: "Parece do domínio do impossível que a cidade que não sendo governada pelos melhores mas sim, ao contrário, governada por maus elementos, tenha uma boa legislação; igualmente, que a cidade governada aristocraticamente não tenha uma boa legislação. Ora, uma boa legislação (eunomia), não é ter boas leis, mas às quais não se obedece. É portanto preciso conceber a eunomia antes de mais como a obediência às leis estabelecidas e, depois, como a excelência das leis estabelecidas que se respeitam fielmente". Apud MOSSÉ, Claude. O cidadão na Grécia antiga. Lisboa Edições 70, 1999. p. 109.

$10 E N, \mathrm{~V}, 1,1129$ b, 19-30; "rightly if the law has been rightly enacted, not so well if it has been made at random". ARISTOTLE. Nicomachean Ethics. cit.

11 Vide FERRAZ JUNIOR, Tércio Sampaio. op. cit., p. 161 e ss. Vide também: COULANGES, Fustel de. $A$ cidade antiga. 
coincide parcialmente com o Constituinte moderno no sentido em que a ambos é reservado o poder "arquitetônico" de determinar a estrutura do poder político. Assim, entre nós, ao Constituinte reserva-se a determinação dos poderes de Estado, dos órgãos de soberania, de suas competências etc., assim como ao legislador de Aristóteles atribui-se a determinação de quais são as magistraturas, seu número, os requisitos de seu exercício etc.

Mas a analogia não pode ser levada muito mais longe. Apesar de, no marco do Constitucionalismo contemporâneo, a matéria constitucional não se limitar à delimitação dos poderes do Estado (limitação esta que não pôde ser observada sequer sob o paradigma do Constitucionalismo liberal), ainda assim é de admitir grandes diferenças com respeito ao quanto Aristóteles atribui ao legislador, a quem reserva, na qualidade de fundador ou reformador da vida comum, o papel honorabilíssimo de grande educador. A lei é a pedra angular, em articulação com a literatura e outras formas de socialização, dos processos de formação (paideia) do homem grego, e assim da constituição ética do homem no interior da comunidade. A lei dispõe sobre todos os temas sobre os quais versa a ética, e por isso os problemas da aplicação da lei (e da eqüidade) assumem tão grande importância em seus tratados éticos. A lei diz sobre o modo como o homem deve agir nas diferentes situações da vida em que há de dominar o seu desejo, orientando o humano no seu esforço por tornar-se virtuoso (no processo de auto-recuperação do homem sério empenhado na construção de seu caráter). Nesse sentido, a lei se vincula à conquista da eudaimonia como felicidade, conduzindo o homem sério a uma vida de sucesso no contexto de sua comunidade concreta. É claro que tudo isto já não tem relação com as preocupações do constituinte contemporâneo, ao menos aos olhos das teorias políticas e das filosofias do Direito predominantes, que entendem, a partir de uma diferente perspectivação das esferas do público e do privado, que os problemas da felicidade não atinem ao Direito.

A visão de Aristóteles distingue-se muito fortemente desta concepção contemporânea; se para "o individualismo liberal, a comunidade é apenas o terreno onde cada indivíduo persegue o conceito de viver bem que elegeu para si mesmo", ${ }^{12}$ para Aristóteles a felicidade não é um problema apenas individual, mas o principal escopo

\footnotetext{
12 MACINTYRE, Alasdair. Tras la virtud. Traducción castellana de Amelia Valcárcel. Barcelona: Critica, 2001. p. 242. Eu duvido, como ele, que cada um possa escolher apenas para si seu conceito de viver bem. MacIntyre, na mesma página, continua o seu diagnóstico do lugar comum da ética moderna: "as instituições políticas existem apenas para garantir a ordem que torna possível essa atividade autônoma. O Governo e a lei são, ou devem ser, neutras relativamente às concepções rivais do viver bem, e por isso, embora o governo tenha o dever de promover a obediência à lei, segundo a opinião liberal não é parte da função legítima do Governo incutir nenhuma perspectiva moral".
} 
da lei e de tudo que é eticamente relevante, ${ }^{13}$ e não creio que sejam dissociáveis em seu pensamento. ${ }^{14}$

A lei atine aos horizontes de todas as virtudes éticas. ${ }^{15}$ Por via de sua relação com a lei, a justiça é afirmada como a excelência completa. Na medida em que ser justo é respeitar a lei, não é possível ser justo sem realizar também todas as demais virtudes do caráter, sobre as quais a lei dispõe: ser justo no sentido de ser respeitador da lei implica ser corajoso, ser generoso, ser comedido nas palavras, ser espirituoso e todas as demais virtudes que tornam o homem excelente em cada situação concreta da vida.

Por isso a justiça é a mais poderosa das excelências, e nem a estrela da manhã nem a da tarde são tão maravilhosas: "A justiça concentra em si toda virtude"; "na justiça se dão, juntas, todas as virtudes". ${ }^{16}$

A justiça como rainha de todas as virtudes

A afirmação da prioridade da justiça entre as virtudes encontra ainda uma outra via de explicitação. Aristóteles remarca que a justiça é a rainha das virtudes "não absolutamente mas na relação com outrem", “é a justiça perfeita porque é a prática da justiça perfeita, perfeita porque quem a possui pode usá-la para com outro". ${ }^{17}$

É completa pois um homem não a usa só para si, mas também com os outros. Muitos são capazes de usar a excelência em assuntos próprios, mas são impotentes para fazê-lo na sua relação com outrem. A justiça comparece como uma virtude que, presente no homem, é um bem que também pertence ao outro, pois pela ação do justo a justiça produz o que é de interesse para outro (seja superior ou igual). ${ }^{18}$

$13 E N, \mathrm{~V}, 1,1129$ b $14-19$.

14 Estou encostando em um tema central da filosofia moral e política contemporânea: a discussão em torno do comunitarismo. Não seria possível evitá-lo se me dedico tão extensamente à interpretação de Aristóteles. O sentido daquela discussão é simples: "os bens são internos às práticas" (MACINTYRE, Alasdair. Justiça de Quem? Qual Racionalidade? Tradução de Marcelo Pimenta Marques. São Paulo: Edições Loyola, 1991. p. 237). Desde um ponto de vista ontológico, construído fenomenologicamente, é impossível negar que todo saber sobre o que é bom ou mau depende do contexto tradicional em que o homem veio a ser quem é. Ao mesmo tempo, é do interior desta tradição que ele parte para o futuro. É evidente que de algum modo o futuro deve-se à tradição, na medida em que é possibilitado pela tradição - mas o futuro não é a repetição da tradição. Mas a tradição está sempre em jogo, e é neste colocar em discussão sempre a tradição (a situação) que reside a afirmação do bom e do mau. De onde o homem vem dá-lhe alguma experiência para enfrentar situações deste tipo, mas o problema do bem decide-se na prática - a cada vez, portanto.

$15 E N, \mathrm{~V}, 1,1129$ b $21-25$.

$16 E N, \mathrm{~V}, 1,1129$ b 29-30.

17 EN, V, 1, 1129 b 31-32. ARISTÓTELES. Ética a Nicómaco. Tradução de António C. Caeiro. Lisboa: Quetzal Editores, 2004. p. 109.

18 O pior de todos é o que é mau para si mesmo e também para outrem, e o melhor de todos é o que aciona a excelência para si e para outrem: tarefa difícil. $E N, \mathrm{~V}, 1,1130$ a 5-8. 
Aristóteles procura chamar a atenção para a transitividade social ${ }^{19}$ da virtude da justiça, a qual, dizendo respeito à distribuição das coisas exteriores necessárias ao sucesso (honras, riquezas e cargos públicos), impõe necessariamente uma mediania a estabelecer na relação do homem com o outro.

Creio, contudo, dever assinalar que esta transitividade - como a necessária referência ao outro no agir - não é uma característica exclusiva da justiça, mas é antes uma característica atribuível a todas as virtudes éticas. ${ }^{20}$ É possível afirmar que, pelo traço da comum referência e implicação do outro, presente em todas as virtudes éticas, todas as virtudes são uma forma de justiça.

A confirmação disso está em que, em todas as situações a que Aristóteles se refere com o fito de exemplificar o agir impulsionado por cada uma das demais virtudes éticas, o homem não se encontra só, mas está para agir diante de um outro homem, a quem a sua ação sempre se refere. A ética não tem por objeto a relação do homem consigo mesmo, mas a sua relação com o outro.

\section{O outro na ética aristotélica}

Este tópico anuncia o essencial da discussão aqui. A presença do outro em toda ação realizadora da virtude ética mostra como o humano não é senão na medida em que convive com o outro, já que a sua constituição ética (o seu caráter) dá-se na medida em que ele age nas diversas situações éticas em que é lançado a cada vez, sendo o resultado de como se desembaraça delas. O que ele é resulta de sua própria autoconstituição ética, a qual se dá sempre ao ensejo do encontro com o outro, pois é uma marca de toda disposição ética (seja virtude, seja vício) o ser uma disposição relativamente a outrem.

A alteridade caracteriza todas as virtudes éticas fazendo delas sempre espécies de justiça (nesse sentido a justiça é o denominador comum de todas as virtudes, ou a síntese total delas: a rainha das virtudes). Toda virtude ética é uma excelência relativamente a outrem. E isto que a marca como uma virtude ética: há outras virtudes do humano que não-implicam essencialmente o outro, como por exemplo o vigor do corpo,

\footnotetext{
19 Sobre a proeminência deste traço da teoria aristotélica da justiça, cf. SALGADO, Joaquim Carlos. A idéia de justiça em Kant. 2. ed. Belo Horizonte: Editora UFMG, 1995. p. 29 e ss.

20 É a opinião também de Nussbaum: "Ao investigar a natureza da justiça, a dikaiosýne, assinala que, em certo sentido, é a "mais perfeita" das excelências e que nela se dão juntas todas as demais, pois toda excelência possui um aspecto de relação com o outro, é dizer, uma faceta social. Enquanto se relaciona com os outros, toda excelência merece o nome de justiça. Aristóteles parece estar afirmando que, consagrada a ocupações e interesses solitários, sem a excelência que consiste em considerar devidamente o bem dos demais, a pessoa humana não apenas priva-se de um bem importante, como de todas as excelências, pois todas e cada uma são "com relação aos outros" (pros heterón), assim como "com relação a um mesmo" (pros hautón)". NUSSBAUM, Martha Craven. op. cit., p. 441.
} 
adquirido pela dieta e pela ginástica, que é decerto uma excelência mas não tem natureza ética.

A implicação do outro distingue o campo da ética. O tipo de situação em que o caráter do homem se forma envolve-o sempre na relação com o outro, com a comunidade. Não há lugar para o solipsismo na ética aristotélica. O outro está ali implicado constitutivamente.

O outro que necessariamente comparece nas situações éticas que a cada vez se constituem não é um tipo, não é um modelo abstrato, não é um outro "em geral": é sempre um homem concreto, absolutamente específico, único. ${ }^{21}$ Em razão de sua singularidade faz-se singular a situação, a qual é sempre irrepetível, nova. A novidade de cada situação, que renova e eterniza (enquanto o homem dura) a tarefa de agir bem como um desafio, deve-se à singularidade dos elementos constitutivos da situação, as quais Aristóteles descreve como suas categorias. ${ }^{22}$ Cada situação é irrepetível em razão da especificidade de suas circunstâncias, e por isso o correto a fazer apenas diz respeito a cada situação concreta (o que impõe o limite de "rigor" à ética e à política como Ciências: elas não podem dizer ao homem de antemão o que é agir/viver bem, mas apenas oferecerlhe indicações gerais). Tudo quanto está em jogo em cada situação é que faz dela aquela situação, em vista de que o homem deverá ser razoável e decidir da melhor forma possível. As categorias da ação ou da situação, a que o homem consciente (lúcido) deve atender adequadamente a cada vez, dizem respeito ao lugar, ao tempo (duração e oportunidade), aos motivos, à maneira do agir assim como especialmente à pessoa com quem se lida. É muito mais vergonhoso bater na própria mãe que num irmão. Há situações, recomendam, que se mate a pessoa com que se lida (o que será mesmo louvado, como na guerra). O que é agir espirituosamente e com bom tom varia conforme alguém conversa com velhos amigos ou com uma autoridade: não são as mesmas as piadas as quais se crê poder contar para diferentes pessoas.

A conduta apenas pode ser decidida a partir das circunstâncias concretas, o que significa especialmente: a partir do outro que está também envolvido no agir.

\footnotetext{
21 Vale aqui a observação que Douzinas e Warrington consignam para esclarecer a ética da alteridade sobre a qual pretendem refundar uma filosofia do Direito pós-moderno, "o outro não é o alter ego do self, ou uma extensão do self. Nem é o outro a negação do self numa relação dialética possível de ser totalizada numa síntese futura. Heidegger enfatiza corretamente a natureza histórica e social do self. Mas o outro não é similar ao self; o self e o outro não são parceiros iguais num "nós" heideggeriano em que dividimos nosso mundo; nem é a externalidade ameaçadora e radical ausência do existencialismo sartriano que transforma o self num objeto. O outro vem primeiro. Ela (ele) é a condição da existência da linguagem, do si e da lei”. DOUZINAS, Costas; WARRINGTON, Ronnie. Postmodern jurisprudence: the law of text in the texts of law. Londres: Routledge, 1991. p. 163-4.

$22 E N$, I, 6, 1096 a 19-23.
} 
É de se assinalar o caráter originário e constitutivo da presença do outro na ética aristotélica. O outro não é alguém que o homem encontra ali, fora de si, independente de si mesmo. $\mathrm{O}$ si não existe antes do outro. $\mathrm{O}$ homem não encontra o homem depois de encontrar a si mesmo, mas se encontra através dos outros, mediante o outro. Através do outro o homem se torna o que ele é.

A importância do outro no processo de constituição ética realça-se também quando se considera a voluntariedade do agir em Aristóteles, remetida do momento concreto do agir para o inteiro processo de constituição do caráter. O caráter é o princípio (causa) do agir, o homem é constituído por uma espécie de conjunto de inclinações as quais, mobilizadas conforme o tipo de situação correspectiva, são capazes de levá-lo a agir desta ou daquela maneira. É claro que existe um espaço de manobra do homem com respeito a suas próprias inclinações; dentro de certos limites (além dos quais o homem está irremediavelmente perdido) o homem a cada ação se decide, e essa decisão tem efeito sobre seu caráter, predispondo-o a agir daquela forma em outras situações do mesmo tipo (ao mesmo tempo, tal margem de manobra impede que se considere o homem como para sempre bom: há sempre o risco da degeneração). Mas a disposição do caráter tem um lugar decisivo naquelas situações em que o homem não tem tempo para pensar no que fará, situações que exigem ou provocam uma reação imediata, não-refletida: nesta oportunidade a sua reação será a expressão direta de suas inclinações éticas. $\mathrm{O}$ corajoso não foge se lhe aparece inesperadamente uma situação de perigo que é justo afrontar, e sua reação será virtuosa (corajosa) por força de sua predisposição para o justo meio nestas situações. Costuma-se dizer que nada mostra melhor o que um homem é do que este tipo de situação, em que ele não tem tempo para pensar, em que não há lugar para o cálculo. Diz-se com isto que um homem se descortina nessas situações, revelando sua efetiva maneira de ser. O que ele é portanto: suas predisposições éticas, suas inclinações (seu caráter). O lugar do outro é muito claro aqui. O outro é a condição de possibilidade de qualquer inclinação no homem, a reação irrefletida e descortinada que ele terá (será) aqui e agora não se dá senão como o resultado de suas ações em situações anteriores que envolveram outros.

O que um homem é, para Aristóteles, não se reduz ao conjunto de inclinações que o predispõem a agir (desejar) de uma maneira (adequada ou não). É claro que este é um aspecto inolvidável do que o homem é, mas uma análise fenomenológica do homem ético deve ainda apreender o ser do homem na sua atividade mais própria, o que para Aristóteles é sem dúvida o pensar, e agora quero focar a questão do outro e do pensar prático. O pensar envolvido nas situações éticas - como deliberação (bouleusis) e como decisão (proairesis) - somente é mobilizado diante do outro, em razão do desafio colocado pelo outro que institui com o agente a situação ética em que se encontra e que enseja ou requer o exercício da sua razão prática. Ou seja, a atuação do homem como pensar, como dianoia (isto é, como ele mesmo, especificamente humano), depende sempre da 
provocação, da presença do outro. Sem o outro não há ação, não há escolha e deliberação, não há ensejo para que o homem seja humano.

Por outro lado, ainda, o outro está antes do homem, pois o seu próprio caráter é fruto do agir de outros homens, que o antecedem. O caráter do homem forma-se por seu agir, mas o homem começa a agir muito antes de ser capaz de decidir-se por si mesmo, muito antes de ser "maior" ética e juridicamente. O processo de conformação do desejo começa na mais tenra idade através da educação, que consiste na domesticação do desejo da criança pela adequada aplicação de prêmios e castigos, pela administração do prazer e da dor conseqüentemente ao seu agir de modo a habituá-la ao justo meio nos diferentes tipos de situação. Quando a criança alcança a maioridade e passa a responder por seu próprio agir (passando a escolher e deliberar a cada vez, assumindo a responsabilidade por sua própria autoconstituição), ela já encontra em si a virtude que a predispõe para o bem, tornando-se-lhe mais fácil encontrar o meio termo a cada situação.

O homem, quando entra na titularidade de sua vida prática (quando lhe advém a maioridade política e ética: civil), já percorreu uma significativa etapa de seu processo de formação, fase essa indispensável para o seu sucesso na realização ética (felicidade). Toda aquela primeira etapa, em que é educado, é realizada sob a direção do outro, cuja decisão substitui a decisão do jovem ainda não emancipado. O outro é absolutamente requerido para a constituição do homem como sujeito ético porque sem o outro (sem a sua colaboração como reitor do processo pedagógico que vai conformar o desejo do agente ético na preparação para sua estréia como responsável), o processo circular característico da ética aristotélica (a disposição que causa a ação que causa a disposição... num círculo virtuoso ou vicioso) não tem como iniciar-se. O processo começa como formação da disposição: o homem já chega para as suas primeiras decisões autênticas na vida prática com certa disposição, a qual deve a um outro que lhe a impingiu, cuidando dele e orientando-o (habituando-o) em situações práticas anteriores.

\section{Conclusão}

O sentido particular da justiça, a especial consideração do outro e a instituição da convivência como uma ordem política

A justiça, afim mas não identificada ou reduzida à lei, revela-se como uma espécie de denominador comum de todas as virtudes, enquanto que todas as virtudes, envolvendo essencialmente o outro, são formas de justiça. Isto permite compreender a afirmação de que a justiça é a virtude/excelência total, e não parte da excelência (ao mesmo tempo em que a injustiça será a perversão total, e não parte dela). 
Esta passagem ${ }^{23}$ introduz outra distinção importante quanto aos usos da palavra justiça: a que aparta a justiça especial (justiça em sentido específico) e a justiça absoluta. Trata-se aí da distinção entre a justiça como a totalidade ou a suma das virtudes (em que se aproxima da lei) e a justiça como uma entre as demais virtudes (virtude em sentido específico: uma entre as outras no catálogo das virtudes). É na distinção entre essas duas acepções de justiça que se compreende o sentido especial com que a justiça é socialmente transitiva para Aristóteles, que pergunta: como se distinguem a excelência em geral e a própria justiça? ${ }^{24} \mathrm{~A}$ interrogação problematiza a distinção entre a justiça em sentido específico e em sentido absoluto, e prossegue na afirmação de que "são disposições do mesmo gênero, como tais idênticas, mas [que] diferem no modo de manifestaremse". Enquanto a justiça manifesta-se relativamente a outrem, a excelência manifesta-se de forma absoluta. Esta passagem ${ }^{25}$ não depõe contra minha interpretação de que todas as virtudes (e não apenas a justiça em sentido estrito) são transitivas na sua implicação do outro. Aristóteles mesmo afirma um pouco mais adiante ${ }^{26}$ que tanto a justiça geral como a justiça particular são relativas a outrem (e assim, como a justiça em sentido absoluto implica o conjunto das virtudes, logo todas as virtudes implicam o outro). O que especifica a injustiça particular é a sua origem no gozo obtido com o lucro, enquanto a injustiça em sentido absoluto (injustiça como resumo de todas as perversidades) atina a tudo o que diz respeito às paixões e aos desejos. $\mathrm{O}$ que enfim distingue a justiça em sentido estrito da justiça em sentido geral é o mesmo que distingue a justiça específica das demais virtudes éticas: todas elas implicam o outro, mas na justiça dá-se de modo peculiar a relação com o outro, ${ }^{27}$ no caso da justiça, a relação com o outro é mediada pelos bens exteriores. Seu horizonte é o encontro do homem com o outro ao ensejo da repartição destes bens, e sua excelência é a mediania ótima em que cada um dos envolvidos naquela situação prática recebe o que lhe cabe (a cada um os bens que lhe cabem - a cada um, o seu).

\footnotetext{
$E N, \mathrm{~V}, 1,1130$ a $23-25$.

$24 E N, \mathrm{~V}, 1,1130$ a $6-14$.

$25 E N, \mathrm{~V}, 1,1130$ a 12-14. Na tradução de Maria Araujo e Julian Marias, diz-se que "é com efeito a mesma, mas sua essência não é a mesma, senão que enquanto se refere ao outro é justiça. E enquanto disposição de tal índole, sem mais ou absolutamente, é virtude". ARISTÓTELES. Etica a Nicomaco. Traducción de Maria Araujo, Julian Marias. Madrid: Instituto de Estudios Políticos, 1970. p. 72.

${ }^{26} E N, \mathrm{~V}, 2,1130$ b 2-3: "ambas têm nisso o seu poder, que são disposições do comportamento relativamente a outrem”. ARISTÓTELES. Ética a Nicómaco. Tradução de António C. Caeiro. Lisboa: Quetzal Editores, 2004. p. 111.

${ }^{27}$ Atine à distribuição do que é vantajoso e prejudicial. "Also, Justice is that quality in virtue of which a man is said to be disposed to do by deliberate choice that which is just, and, when distributing things between himself and another, or between two others, not to give too much to himself and too little to his neighbor of what is desirable, and too little to himself and too much to his neighbor of what is harmful, but to each what is proportionately equal; and similarly when he is distributing between two other persons". Rackham ARISTOTLE. Nicomachean Ethics. cit.
} 
De toda sorte, Aristóteles esclarece que o Livro V da Ética a Nicômaco trata da justiça em sentido específico, considerada assim como uma virtude ao lado das outras (a justiça como parte da virtude total). Neste sentido a injustiça será a perversão ou a maldade em razão da qual o homem quer ter mais do que é devido (injustiça em sentido específico).

A afinidade entre a justiça e as demais virtudes agudiza o problema da sua distinção recíproca. Na medida em todas as perversões são formas da injustiça, como distinguir a injustiça e o injusto em sentido estrito? Isto é, como distinguir uma ação injusta de uma ação covarde, ou luxuriosa? Cada uma das virtudes é uma forma de justiça (e, assim, todo vício é uma forma de injustiça); a questão que se coloca é como saber se se está diante de uma ação elogiável ou reprovável por ser especificamente justa ou injusta?

$\mathrm{O}$ critério distintivo será encontrado no motivo fundamental do ato, ${ }^{28}$ que se confunde com o seu fim. O motivo da ação é o que define a espécie de virtude que está em jogo no agir; por exemplo, se uma determinada ação reprovável o é enquanto um ato luxurioso ou um injusto. Toda ação reprovável pode ser reconduzida a uma disposição perversa, àquilo que faz com que a ação seja considerada perversa. No caso da justiça, o motivo fundamental do agir injusto é o lucro, ${ }^{29}$ e não qualquer outro fim reprovável (como a luxúria ou a paixão, por exemplo).

Um homem pode praticar uma injustiça e não ser considerado injusto. Que tipo de ato torna o homem injusto, no sentido específico de injustiça? ${ }^{30}$

A qualidade da ação a ser louvada ou reprovada depende essencialmente do motivo do agir. Assim, o adúltero ao se deitar por paixão (e não por eleição ${ }^{31}$ ), não se torna injusto, mas devasso. O mesmo vale para as demais manifestações de injustiça. ${ }^{32} \mathrm{~A}$ escolha deliberada tem em vista ali não a satisfação da libido mas uma outra vantagem que lhe satisfaça a ganância.

O que determina o caráter especificamente justo ou injusto (ou enfim, de que virtude ou vício se trata) não é o resultado ou a qualidade do ato, mas o motivo da ação deliberada. Isto é, o seu princípio.

O homem injusto tem o mau hábito de querer mais do que lhe cabe nas situações de repartição das coisas exteriores. A injustiça que comete determina-se como tal não em razão de quaisquer outras perversões, mas em razão da sua própria disposição para

\footnotetext{
$E N, \mathrm{~V}, 6$.

$E N, \mathrm{~V}, 2,1130$ a $25-29$.

$E N, \mathrm{~V}, 6,1134$ a 17.

1 EN, V, 5, 1134 a $20-21$.

$32 E N, 1134$ a $24-25$
} 
a injustiça, isto é, por sua própria ânsia por ter mais do que lhe cabe: a ganância. ${ }^{33} \mathrm{O}$ injusto é o ganancioso. $\mathrm{O}$ esforço de Aristóteles em distinguir o caráter injusto ou o ato injusto das demais perversões ou atos reprováveis revela nitidamente a razão de ser, a injustiça, a pior das perversões, pois revela como o injusto é capaz de cometer atos próprios de qualquer outra perversão, movido no entanto pelo seu simples desejo de ter mais do que lhe cabe. $\mathrm{O}$ homem ganancioso é capaz de se deitar com a mulher do outro em troca de dinheiro, e sua ação é ali considerada injusta e não luxuriosa pois o desejo que o move é o lucro e não o prazer sexual. Igualmente, será capaz de abandonar seu concidadão sozinho numa batalha se isto lhe trouxer qualquer vantagem econômica: também esta ação será considerada injusta, pois lhe move o lucro, e não a covardia. ${ }^{34}$

Aganância-a injustiça em sentido específico - é o pior dos vícios exatamente porque ela leva o homem a cometer atos reprováveis próprios de todas as perversidades sem que ele esteja, a cada vez, premido pelas afecções, sentimentos e paixões próprias de cada uma delas (o ganancioso pode cometer o adultério sem que seu desejo sexual o arraste a tanto, ou fugir do perigo que deveria enfrentar sem que seu medo o arraste). Ele não tem sequer a possível atenuante de estar, a cada caso, dominado pelas paixões que dominam o homem não temperado... Ao contrário, o injusto parece o pior dos humanos porque ele parece capaz de controlar em geral seu desejo, curvando-se para o mal no entanto movido por sua cupidez.

Este é um ponto importante: o injusto em sentido específico é aquele cujo caráter o predispõe a tomar mais do que lhe é devido (do que é bom, ou menos do que é mau), pelo simples hábito de desejar mais do que lhe cabe. É uma forma de perversidade radical que atinge o homem todo, tornando-o vil em todas as suas transações com outrem. ${ }^{35}$

Isto enfim ilumina o modo como o outro é especialmente considerado nesta virtude específica: a perversão do injusto é tomar para si o que cabe ao outro, independentemente de quem seja o outro com quem lida. Inversamente, a virtude da

\footnotetext{
33 EN, V, 2, 1130 a 29-33. FERRAZ JUNIOR, Tércio Sampaio. Estudos de filosofia do direito. Reflexões sobre o poder, a liberdade, a justiça e o direito. 2. ed. São Paulo: Atlas, 2003. p. 180: “Todos os ditos injustos (...) correspondem a um vício particular (o adultério à concupiscência, o abandono de um amigo à covardia etc.), mas ao amor ao ganho indevido somente corresponde a palavra injustiça, tomada, então, num sentido específico e particular".

$34 E N, \mathrm{~V}, 2,1130$ b 1-5.

35 É grave constatar que este vício (a injustiça) alastre-se hoje: é muito difundida a disposição por ter mais do que nos cabe, se for possível. A relação do humano com as coisas tende mais a um "obter tanto quanto for possível", independentemente do quanto caiba a cada um. Isto tem algo a ver com a lei ter-se tornado apenas um limite externo à possibilidade de obtenção de ganho na relação com o outro. O canalha vê a lei como o único obstáculo à sua obtenção da coisa, na relação com o outro. Não lhe passa pela cabeça qualquer consideração de justiça. A lei até pode ser o meio de alcançar tudo quanto seja possível mesmo que para além do que lhe caiba. Já não há mais qualquer relação entre a lei e o caráter do humano, ou entre o que a lei determina e o que o humano deseja; o resultado é a erosão da efetividade da lei, ou a oportunista deturpação de sua teleologia.
} 
justiça é o hábito louvável de dar ao outro o que lhe cabe independentemente de quem seja o outro com quem se trate. Na virtude da justiça, há uma especial forma de considerar o outro como outro simplesmente, tal que a torna singular.

Isto não implica que a qualidade particular do outro envolvido na situação seja desconsiderada, e que assim o outro perca sua face e seja despido de sua concreta singularidade, pois esta não pode nunca ser desconsiderada se a ação toma na devida conta as circunstâncias concretas da ação (assim, por exemplo, é diferente o ato - se é justo ou injusto - de um açoite se ele foi praticado por uma pessoa qualquer ou se pela autoridade pública $^{36}$ ). Enfim a face peculiar do outro com quem se lida, mesmo na justiça, não pode ser ignorada sob pena de não se encontrar o justo meio, ou em outras palavras de não se poder determinar o que cabe a cada um.

A peculiar forma da consideração do outro está na predisposição que a justiça é de conceder sempre ao outro o quanto lhe caiba, e de estabelecer assim uma igualdade como proporcionalidade entre aqueles entre os quais a justiça vige. Sem comprometer a singularidade do outro (sempre implicada em qualquer situação) a justiça em sentido específico inaugura uma instância de igualdade a partir da qual todos são considerados como iguais, com o direito de receberem cada qual o que lhe cabe, conforme um critério de proporcionalidade.

Está bem que a justiça é uma noção vazia, como adverte Ferraz Junior. ${ }^{37}$ Isto é ínsito ao seu sentido como igualdade proporcional, mas não significa que uma teoria da justiça deva deter-se neste ponto. Parece-me que o reconhecimento do caráter abstrato da igualdade apenas se presta a expor o problema que é, ele mesmo, o centro da teoria da justiça como uma teoria política da justiça: a definição do conteúdo da igualdade.

A determinação do critério ou do conteúdo da igualdade não pode a ética como teoria da justiça oferecer, pois apenas a integração do agir numa ordem política concreta, num regime político histórico, pode indicar o que vale como critério acerca

\footnotetext{
$E N, \mathrm{~V}, 5,1132$ b 26-31.

37 Que sublinha e tira conseqüências importantes deste caráter abstrato da justiça, anotando que "se a igualdade é uma abstração, pois os homens são, na realidade, profundamente desiguais, é fato também que da exposição de Aristóteles só se pode deduzir a relação entre as pessoas, mas não o modo de tratá-las concretamente. A justiça não é, nesse sentido, um princípio exaustivo, capaz de resolver um problema tipicamente humano, qual seja, o da convivência. E Aristóteles tem um sentimento desse inacabamento e da conseqüente necessidade de outros preceitos quando (...) estabelece as relações entre a justiça e a equidade ( $E N, \mathrm{~V}, 14,1137$ a 31$)$ ". Tércio raciocina: "se é unânime o reconhecimento de que a justiça é uma espécie de igualdade $(E N, \mathrm{~V}, 6,1131$ a 12 ; Pol., III, 12, 1282 b 18), é inevitável que se pergunte, porém, sobre o que versa a igualdade, isto é, igualdade de que realiza a justiça? A resposta a esta pergunta pertence à ciência política", como afirma Aristóteles. FERRAZ JUNIOR, Tércio Sampaio. op. cit., p. 183.
} 
do que cabe a cada um naquela ordem concreta. A ética só pode fazê-lo tornando-se política. ${ }^{38}$

Mas qual o valor da doutrina da justiça como uma virtude na relação com o outro, como respeito à pertença do outro como outro? Ferraz Junior tem razão ao afirmar que a justiça não resolve o problema "tipicamente humano da convivência". Mas o seu sentido próprio não é o de ser uma forma de resolver este problema, mas sim o de instituílo. A justiça apenas institui como um problema a questão do critério da determinação proporcional do que cabe a cada um, ciente de que este problema apenas pode ser resolvido pela política.

A ética (a justiça), ao fazê-lo, não se torna refém da política, mas antes a justiça institui a política como um modo de coexistência em que a questão sobre o que cabe a cada um é um problema a ser resolvido segundo um critério proporcional.

São Paulo, agosto de 2008.

\section{Referências}

ARISTÓTELES. Ética a Nicómaco. Tradução de António C. Caeiro. Lisboa: Quetzal Editores, 2004.

. Etica a Nicomaco. Traducción de Maria Araújo, Julian Marias. Madrid: Instituto de Estúdios Políticos, 1970.

. Nicomachean Ethics. Translated by H. Rackham. London, Cambridge: Harvard University Press, William Heinemann, 1934. Disponível em www.perseus.tufts.edu.

. Aristotle's Ethica Nicomachea. Recognovit brevique adnotatione critica instruxit I. Bywater, Scriptorum Classicorum Bibliotheca Oxoniensis. Oxford: Clarendon Press, 1890. Disponível em www.perseus.tufts.edu.

. A política. Tradução de Nestor Silveira Chaves. 4. ed. São Paulo: Atena Editora, 1955.

\footnotetext{
38 Vista por este ângulo, toda a Ética a Nicómaco parece uma preparação do terreno para $A$ Política, onde Aristóteles afirma o mérito como o critério eticamente relevante para determinar a medida dos homens e assim a justiça em cada troca, assim como para fundar uma associação política perfeita. Aristóteles tem isto em mente quando distingue a justiça como lei da justiça em sentido absoluto. Toda lei é "de alguma forma justa" porque impõe uma mediania apurada em conformidade com a igualdade vigente naquela ordem política concreta, seja aristocrática ou democrática. Mas permanece o tom crítico ou o direito do ético de aquilatar o valor ou a justiça da própria ordem, por via da crítica ao critério adotado pela lei para afirmar a igualdade entre os homens (e o seu direito de acesso às magistraturas, ao poder político). A ética não pode prescindir de dizer este critério; ela não se cala ante è política nestes assuntos, mas ela se faz política para defini-lo. Se um homem não pode ser bom senão numa ordem boa e se a ética objetiva fazer o homem bom, a ética culmina (ou principia) pela definição da justiça da própria ordem, determinando o conteúdo da igualdade que lhe está na base.
} 
DOUZINAS, Costas; WARRINGTON, Ronnie. Postmodern jurisprudence: the law of text in the texts of law. Londres: Routledge, 1991.

FERRAZ JUNIOR, Tércio. Estudos de Filosofia do Direito. Reflexões sobre o poder, a liberdade, a justiça e o direito. 2. ed. São Paulo: Editora Atlas, 2003.

MACINTYRE, Alasdair. Justiça de quem? Qual racionalidade? Tradução de Marcelo Pimenta Marques. São Paulo: Edições Loyola, 1991.

. Tras la virtud. Traduccion castellana de Amelia Valcárcel. Barcelona: Crítica, 2001.

MOSSÉ, Claude. O cidadão na Grécia antiga. Lisboa: Edições 70, 1999.

NUSSBAUM, Martha Craven. La fragilidad del bien. Fortuna y ética en la tragedia y la filosofía griega. Traducción de Antonio Ballesteros. Madrid: Visor, 1995.

SALGADO, Joaquim Carlos. A idéia de justiça em Kant. 2. ed. Belo Horizonte: Editora UFMG, 1995. 